\section{Os cordões do imaginário daquém e dalém mar}

\author{
HORÁCIO COSTA
}

Em Lisboa, das ameias da torre de menagem do castelo de São Jorge, em direção ao oeste, ao estuário do Tejo, descortina-se, já meio apagada pela distância e além da ponte 25 de Abril, a neoclássica silhueta do palácio da Ajuda: os três frontões que dividem em dois o horizontal da fachada principal do palácio, última residência dos reis portugueses, levantam-se altaneiros sobre a massa urbana. Numa linha imaginária, à direita do rio, ameias conversam com frontões, castelo com palácio, sobre o teatro da Lisboa histórica: entre estes dois pontos focais sucedem-se a Baixa, a colina do Carmo que dá entrada ao Bairro Alto, e assim por diante, até as alturas da Ajuda, dominadas pela real morada.

O que não pode ver do castelo, quem na direção do palácio olha, é a pequena casa a ele fronteira, tão humilde - se a compararmos ao porte da mole de mármore da qual a separa uma praça - quanto significativa: nela viveu e trabalhou, por décadas, o grande Alexandre Herculano, exercendo a função de bibliotecário-chefe da Real Biblioteca da Ajuda; nela, por décadas, Herculano revisou a memória nacional portuguesa e pôde oferecer, assim, às gerações futuras, uma nova interpretação da história lusitana.

Não conheço nenhum espaço mais imantado de simbolismo, e por isso mesmo mais paradigmático, sobre o relacionamento sempre diff́cil, embora necessário, do intelectual com o Poder, quanto este delimitado pela praça (ou será, à portuguesa, "terreiro"?) da Ajuda. A pequena casa de Herculano lá está plantada como um resistente desafio, face a face ao histrionismo esfíngico do poder temporal. Que suas obras tivessem refletido a complexidade de seu relacionamento com o Poder não surpreende a ninguém familiarizado com a literatura portuguesa: a revisão de Herculano sobre as versões entronizadas do que fora a história nacional, feita no século XIX, em sua produção de historiador e de ficcionista, abriu caminhos fundamentais para o pensamento português no século em curso. A moderna literatura lusa nos mostra que os ensinamentos de Herculano frutificaram: a obra de José Saramago é um bom exemplo disso e, nela, o romance História do cerco de Lisboa sem dúvida ocupa um lugar de destaque. Em seu último romance, Saramago afirma e aprofunda a temática da convivência do cidadão comum com as formas de organizaçấo do poder social e polf́tico, uma das mais importantes das quais é, sem dúvida, sua relação com a dimensão histórica marcada pelo placet do poder instituído.

Na obra de Saramago, este trabalho sobre os possíveis horizontes históricos, ou ainda sobre a clivagem intransponivel entre vida individual e a face oficial da vida coletiva, já assumira contornos nítidos em pelo menos dois de seus mais importantes romances. Em Memorial do convento, a romancização da construção do "monstrengo" de Mafra dá ensejo a uma alegoria complexa (e barroca) sobre a necessidade do Espírito de projetar seu vôo liberador a regiōes mais gratas para seu próprio desenvolvimento, simbolizado pela Passarola do "herético" Bartolomeu Lourenço de Gusmão. Por sua vez, a relação sujeito/atualidade histórica, da qual decorre a irisão daquele e a relativização

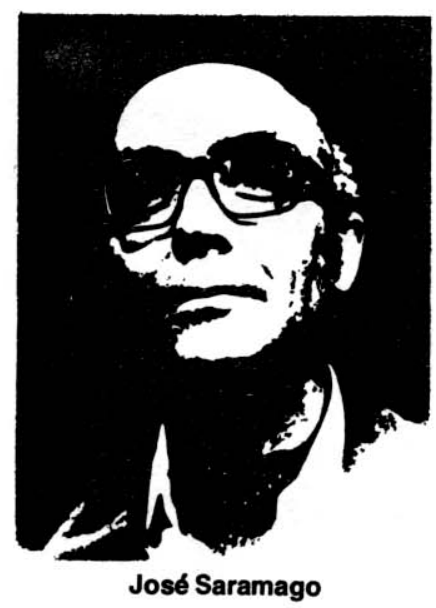

HORÁCIO COSTA é professor de Literatura Brasileira na Universidade Nacional do México e autor de Satori (Editora lluminuras).

Historia do cerco de Lisboa, José Saramago. Săo Paulo, Companhia das Letras, 348 pp. 


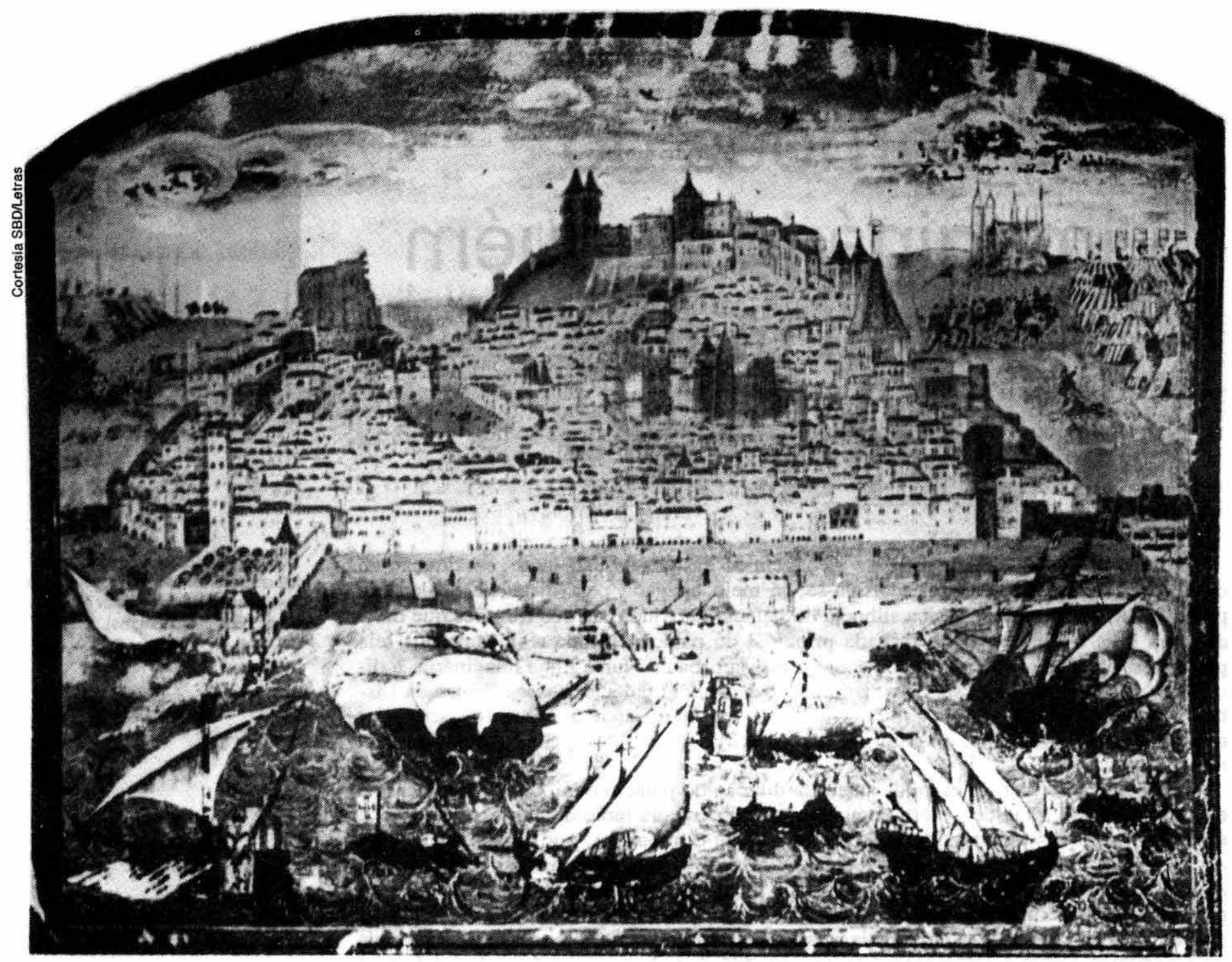

Lisboa medieval, segundo iluminura da Cronica del Rey Dom Affonso Hamriques, de Duarte Galvão (séc. XVI) desta, foi esplendidamente focalizada pelo escritor em $O$ ano da morte de Ricardo Reis. Em ambos romances mencionados, o nível bastante abstrato do tema ao qual me refiro, embora perpasse o texto, encontra-se minimizado (diria: des-teorizado através da pragmática da escritura) pelo exercício de uma linguagem sempre atenta para absorver, tanto pelas suas características "miméticas" (explodindo em intertextualidade com o Barroco e com o Modernismo, com Vieira e com Pessoa, nos livros referidos), como a partir de suas invençōes formais (por exemplo, a do uso do diálogo como inciso no texto, ou ainda uma constante digressividade que tem sua matriz na textualidade nonchalante de Almeida Garrett), o assunto tratado. Em História do cerco de Lisboa essas características não só se mantêm como se intensificam.

Consideremos um momento tão epifânico quanto atormentado, no qual um "homem comum" se rebela, premido pela irrefreável imposição do seu imaginário, para fundar uma nova versão sobre um episódio fundacional da nacionalidade. Consideremos que este "homem comum" $€$, não por acaso, um revisor tipografico que, farto das gritantes falsidades da história oficial, resolve inserir um monossilábico e voraz "não" antes de uma frase que traduz a verdade histórica irrecusável: a de que os cruzados "sim" ajudaram os cristãos a conquistar Lisboa aos mouros, capitaneados por Afonso Henriques no ano de 1147, nos albores de Portugal. Consideremos o título do livro que o revisor está a rever: "História do cerco de Lisboa", tratado histórico de algum adiposo autor acadêmico cujas opiniões convencionais sobre historiografia e fato histórico, expostas num vertiginoso diálogo com o humilde revisor, dão a ouverture ao livro de Saramago. 
Vale dizer que este

esquema narrativo (do

livro) - o da inserção de um

"romance hisłórico"

no bojo de um romance

que não o é, mas que passa

a sê-lo tangencial e

exclusivamente a partir

dessa inserção

mesma - tem um

"pedigree" firmemente

estabelecido nas

literaturas escritas em

português: basta-nos

lembrar de "A ilustre casa

de Ramires", de Eça de

Queirós (no qual Gonçalinho

escreve a história de seus

antepassados bárbaros)

e de "Caetés",

de Graciliano Ramos
Obrigado pelas circunstâncias advindas de sua minúscula rebelião contra a verdade histórica, o revisor pôr-se-á a escrever uma nova "história do cerco de Lisboa" que contradirá, pelo menos em parte, a monolítica memória herdada, construindo uma narrativa que se afastará da história comprovável para, ainda que timidamente, abraçar o domínio da ficção. Vale dizer, paralelamente, que este esquema narrativo - o da inserção de um "romance histórico" no bojo de um romance que não o é, mas que passa a sê-lo tangencial e exclusivamente a partir dessa inserção mesma - tem um pedigree firmemente estabelecido nas literaturas escritas em português: basta-nos lembrar de A ilustre casa de Ramires, de Eça de Queirós (romance no qual o ocioso Gonçalinho escreve a história de seus antepassados bárbaros e, em decorrência disso, tonifica-se para enfrentar os desafios do tempo presente) e de Caetés, de Graciliano Ramos (no qual João Valério tenta infrutiferamente resgatar para o prosaico momento presente as "raízes" de um mítico, e dar inconjugável, passado histórico pré-lusitano), ambos livros testemunhas da importância dos desdobramentos do tema de inspiração histórica - ou do relacionamento personagem de ficção/dimensão histórica - nas literaturas portuguesa e brasileira.

O espaço onde a substituição da primeira "história do cerco de Lisboa" (a do professor), para todos os efeitos ausente do romance de José Saramago a não ser como fator condicionante de sua estruturação (embora, infere-se, fosse ela a única "história" plenamente passível de adequar-se a esta terminologia, já que, supōe-se, seria totalmente dependente da organização retó-

rica que preside o discurso historiografico), pela segunda "história do cerco de Lisboa" (a do revisor), que passa a constituir-se, desta maneira, na crítica de sua anterior, se dá, é na História do cerco de Lisboa que nós lemos. Por sua vez, esta "história" que temos nas mãos não pode ser considerada por completo, não só por estar nela dramatizada a relação entre historiografia e ficção, como também devido ao fato que, na verdade da leitura, o plano narrativo que domina o romance trata de uma outra "história", totalmente ficcional: a do envolvimento amoroso do revisor, Raimundo Benvindo da Silva, com sua superiora hierárquica na editora para a qual trabalha, a urbaníssima doutora Maria Sara.

Tudo isso posto, perceberemos o cuidado de Saramago em não fatigar o leitor com hirsutas explanações sobre o tema da interação do sujeito individual com a memória coletiva e com o registro por excelência desta, a História, fazendo-o conviver com outros temas que acodem com não menor freqüência à sua obra. Sem dúvida, o relacionamento humano de Raimundo com Maria Sara recorda-nos o desenvolvido por outros pares de personagens saramaguianos, como o casal simbolicamente denominado pelas iriiciais H. e M. em Manual de pintura e caligrafia (1977) e aquele formado pelo par Baltasar e Blimunda no já mencionado Memorial do convento (1982). Ainda, o processo de redescoberta de sua identidade profunda, por parte do personagem masculino em idade madura, é recorrente na obra de José Saramago. Escritor que como poucos sabe analisar a mecânica do amor masculino maduro, alêm de havê-lo feito nos livros antes citados, Saramago abordou o tema em $O$ ano da morte de Ricardo Reis (1984) e em A jangada 


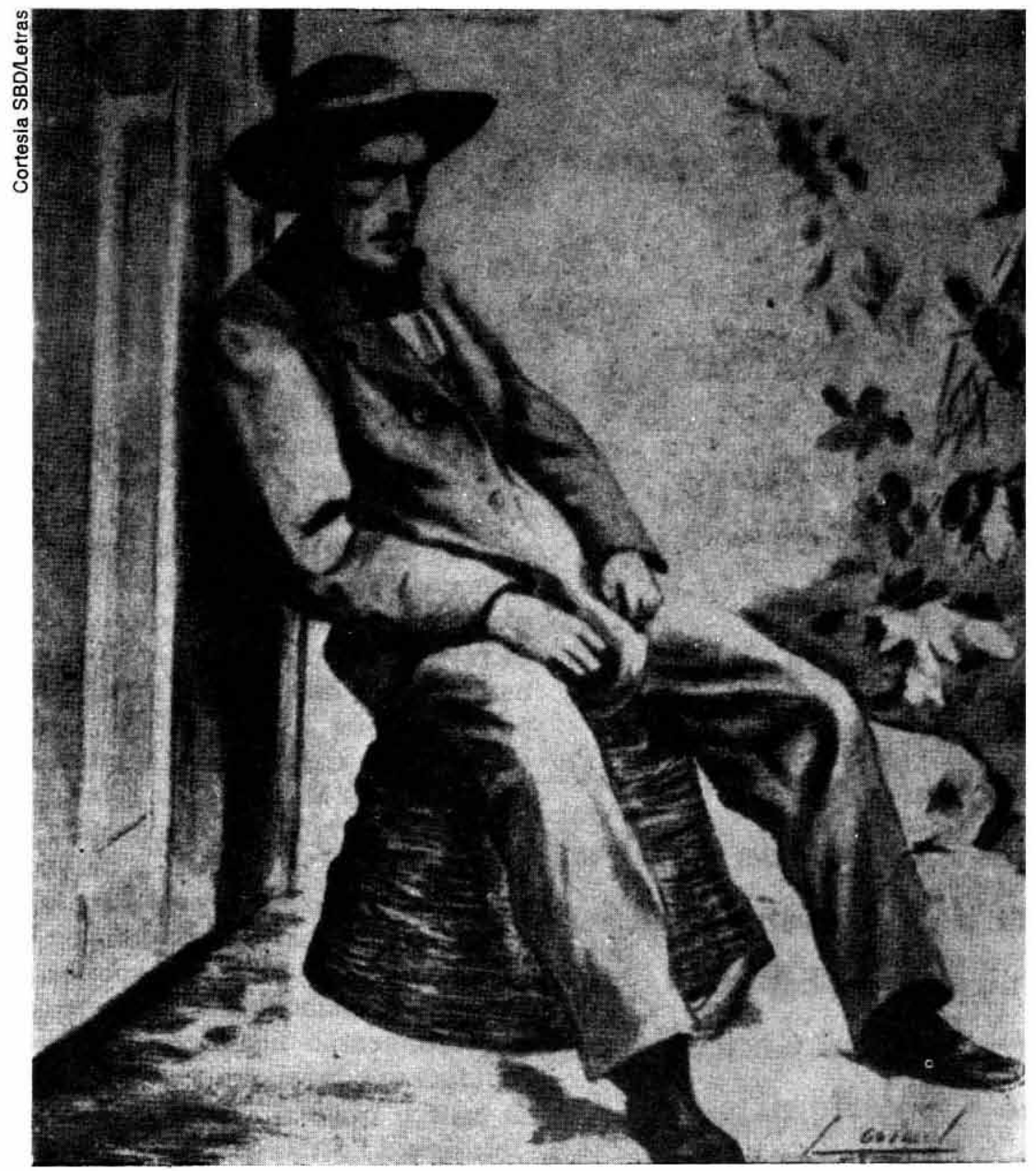

Retrato do escritor romântico portugués, desenhado a partir de uma foto de Dulac de pedra (1986). Por sua vez, o gesto de pequeno heroísmo de Raimundo Silva filia-se aos que embasam algumas das peças de teatro do escritor português, como $A$ noite (1979) e, mesmo, Que farei com este livro? (1980). Como vemos, como é usual no universo literário de um grande escritor, estruturas narrativas, temas e situações, personagens e outras constantes composicionais parecem migrar de um livro para outro, dando origem a verdadeiras "famflias" literárias que seus leitores passam a reconhecer em suas obras.

Tanto quanto nos livros anteriores, neste romance a língua desempenha um papel fundamental: é veículo da narração, mas também narra-se a si própria, já que não poupa o autor uma rica gama de referências textuais (quando não ortográficas) à história da língua portuguesa. Em História do cerco de Lisboa, aqui e ali brilham efeitos-colagem de textos do protoportuguês que manejavam os primeiros cronistas medievais; aqui e ali é-nos possível rastrear a presença do primeiro grande escritor da língua, Fernão Lopes (século XV); aqui e ali uma construção arcaizante ou um vocábulo carregado de memória recorda-nos que a historicidade do idioma é indissociável da história da nacionalidade.

Por todos esses motivos, História do cerco de Lisboa é um grande romance que veio para ficar. Neste sentido, não é demais pensar que, da mesma maneira que na vizinhança do palácio da Ajuda, aquele que vê Lisboa estender-se da torre de menagem do castelo de São Jorge pode imaginar o vulto de Herculano como um reminder da relação intelectual/Poder, um outro observador que dos altos da Ajuda olhe para o castelo, depois da publicação desta História do cerco de Lisboa poderá mesmo visualizar, ao pé da esplêndida mole medieval, o trânsito de um certo Raimundo Benvindo da Silva, revisor de profissão, e sentir o exemplo do poder que tem a boa literatura de fazer chegar ao leitor, de uma maneira aparentemente singela, e manejando apenas os cordões do imaginário, as mais complexas problemáticas.

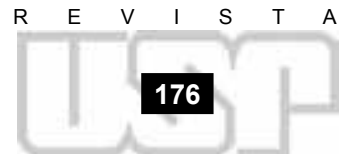

Setembro

Outubro

Novembro 1990 